\title{
Peranan Cita Hukum dalam Pembentukan Hukum Nasional
}

\author{
Riri Nazriyah
}

\section{Abstract}

The formation of national law recently stressed more on formal and positivistic legal aspect so that the product of law created is more practical and pragmatic. For this reason, it needs to renovate in the process of law formation itself by referring to the value and idea of Indonesian law. Besides that, the law formation is still stronger philosophically and sociologically.

\section{Pendahuluan}

Bagi negara Indonesia yang berdasar atas hukum, pembangunan harus dilaksanakan berdasar atas hukum dan dipertanggungjawabkan menurut hukum. Hukum dijadikan prinsip pokok yang harus diterapkan dan dipegang teguh dalam perencanaan, pelaksanaan, dan pengawasan pembangunan, agar penyelenggaraan pembangunan berjaian tertib, teratur dan terkendali, efektif dan efisien guna meningkatkan kualitas manusia dan masyarakat Indonesia seluruhnya. ${ }^{1}$
Begitu pentingnya hukum bagi kehidupan masyarakat, pemerintah Indonesia melalui GBHN 1993 berupaya untuk mewujudkan dan memberikan perhatian yang lebih besar pada pembangunan sistem hukum, dengan menempatkan pembangunan di bidang hukum sebagai bidang yang berdiri sendiri. Dengan demikian, pemerintah diharapkan akan lebih serius dalam menangani berbagai persoalan yang bertalian dengan sistem hukum nasional yang meliputi tiga subsistem

'Oka Mahendra. "Proses pemantapan Cita Hukum dan Penerapan Asas-asas Hukum Nasional Masa Kini dan di Masa yang Akan Datang." Majalah Hukum Nasional. Edisi Khusus 50 Tahun Pembangunan Nasional I. 1995. HIm. 107. 
hukum, yakni: Pertama, subsistem penciptaan atau pembentukan hukum; Kedua, subsistem hukum yang bertalian dengan isi atau materi. hukum baik berupa asas-asas hukum maupun kaidah-kaidah hukum; dan Ketiga, subsistem penerapan dan penegakan hukum. ${ }^{2}$ Tiga subsistem dari sistem hukum nasional tersebut merupakan satu kesatuan yang integral dalam pembangunan di bidang hukum.

Permasalahan terhadap pembentukan sistem hukum nasional, tidak akan terlepas dari landasan filosofis, sosiologis dan yuridis. Bangsa Indonesia sebagai suatu negara yang merdeka tentu ingin membangun bangsanya sesuai dengan nilai-nilai yang dianggap baik dan ideal sesuai dengan falsafah yang diyakininya, yakni Pancasila. Pembentukan sistem hukum nasional harus mengacu kepada dasar falsafah .Pancasila. Karena Pancasila merupakan cita hukum Indonesia yang menjadi penentu arah kehidupan sebagai rakyat yang teratur, untuk membangun negara yang merdeka, bersatu, berdaulat, adil dan makmur. ${ }^{3}$

Landasan sosiologis dimaksudkan bahwa pembentukan sistem hukum nasional harus berpihak dan sekaligus berdiri di atas kepentingan rakyat secara keseluruhan. Artinya, pembentukan sistem hukum nasional harus mampu menciptakan keadilan dan ketertiban dalam masyarakat luas. Landasan yuridis, yang meliputi kewenangan materi atau isi, dan sinkronisasi. Artinya, bahwa dalam pembentukan sistem hukum nasional harus jelas lembaga atau pejabat yang berwenang untuk membuatnya.

Permasalahan di sekitar landasan filosofis, sosiologis dan yuridis mempunyai kaitan erat dalam pembentukan sistem hukum nasional. Oleh karena itu, penerapan berbagai landasan tersebut mempunyai arti yang sangat penting dalam upaya pembentukan sistem hukum nasional.

Berkaitan dengan pembentukan sistem hukum nasional dengan segala dinamika dan problematikanya, maka pembangunan sistem hukum nasional di era reformasi ini terasa sangat mendesak untuk segera dilakukan. Hal ini bukan saja karena pembangunan sistem hukum di masa Orde Baru terasa dikesampingkan oleh Pemerintah, namun juga tekad bangsa Indonesia yang sejak awal lahirnya negara mempunyai komitmen untuk hidup dalam wadah negara hukum yang sesuai dengan landasan Pancasila dan Undang Undang Dasar 1945. Dengan kata lain, di era reformasi yang telah mengubah perjalanan bangsa Indonesia dari langgam otoritarian menuju kepada langgam demokrasi, maka supremasi hukum diletakkan sebagai acuan bersama oleh bangsa Indonesia.

Salah satu agenda penting yang telah dilakukan oleh Pemerintah di era reformasi ini dilakukannya perubahan Undang-Undang Dasar 1945, yang dianggap masih banyak mengandung kelemahan dan sudah tidak sesuai lagi dengan perkembangan zaman. Reformasi politik dan ekonomi yang bersifat

2Bagir Manan. "Pemahaman Mengenai Sistem Hukum Nasional." Makalah Kuliah pembukaan (Pra Pasca) Program IImu Hukum Pascasarjana UNPAD. Bandung. 1994, Hlm. 15-19.

${ }^{3}$ Ruslan Saleh."Pembinaan Cita Hukum dan Penerapan Asas-asas Hukum Nasional." Majalah Hukum Nasional. Edisi khusus 50 Tahun Pembangunan Nasional I $1995 \mathrm{HIm} .49$ 
menyeluruh tidak mungkin dilakukan tanpa diiringi oleh reformasi hukum. Reformasi hukum yang menyeluruh juga tidak mungkin dilakukan tanpa didasari oleh agenda reformasi ketatanegaraan yang mendasar, dan itu berarti diperlukan adanya constitutional reforrm yang tidak sètengah hati. ${ }^{4}$

Sekarang, Undang-Undang Dasar 1945 memang sudah mengalami perubahan yang sangàt substantif. Pada 1999 telah ditetapkan adanya perubahan pertama, pada 2000 telah diterima adanya perubahan kedua, demikian juga pàda bulan Agustus 2001 telah ditetapkan dan disahkan lagi perubahan ketiga UndangUndang Dasar 1945. Perubahan UndangUndang Dasar 1945 ini dimaksudkan untuk memenuhi tuntutan reformasi agar tercipta rasa keadilan dan mampu menjawab semua permasalahan dalam realitas kehidupan masyarakat yang sedang berkembang.

Apabila dicermati secara mendalam hasil amandemen pertama, kedua, dan ketiga Undang-Undang Dasar 1945 perlu ditinjau ulang karena masih ada beberapa pasal yang menonjolkan kompromi politik yang sebetulnya berimplikasi jangka pendek. Dengan kata lain, pembentukan hukum lebih bersifat práktis pragmatis, sebab dilihat dari kóndîsinya perubahan Undang-Undang Dasar 1945 dilakukan seketika setelah tumbangnya Orde Barü (yang mensakralkan UUD 1945), dimana pada masa itu hukum hanya digunakan untuk melanggengkan kekuasaan. Kekuasaan mengkooptasi hukum - meminjam istilah Moh. Mahfud MD., ${ }^{5}$ - pada era Orde Baru terjadi pemerintahan otoritarian yang dibentúk melalui prosedur kondisional dengan misalnya dibuat melalui DPR yang secara "formal" săh jadi melalui rekayasa formal dalam pembuatan peraturan. Di mana dalam ilmu hukum administrasi negara disebut "atribusi kewenangan".

\section{Cita Hukum Indonesia}

Cita hukum bangsa dan rakyat Indonesia yang hidup pada waktu zaman kolonia! bertentangan dengan cita hukum kolonial: Asas-asas hukum kolonial adalah pengingkaran terhadap Hak Asasi Manusia (HAM), juga berwatak diskriminatif antara bangsa Belanda yang berkuasa kontra rakyat Indonesia yang dijajah, selain itu bersifat sewenang-wenang. Semua itu bermuara ke situasi umum dengan tidak adanya kepastian hukum bagi bangsa indonesia.

Istilah umum pada waktu itu adalah "hantam kromo". "Kromo" sebagai tipe rakyat Indonesia harus dihantam. Bukan dibela, yang dibela adalah "Londo". Dalam adagium hukum kolonial "bela londo". Sebaliknya cita hukum nasional pada waktu itu adalah. "bela kromo" dan "hantam londo", yang bermakna hukum harus membela rakyat !ndonesia dan melawan hukum kolonial belanda. Itulah inti jiwa cita hukum nasional.

Oleh kárena itu, cita hukum nasional yang pada waktu itu bersemi dalam hati nurani

${ }^{4}$ Jimly Asshiddiqie."Undang Undang Dasar Kesatuan Indonesia: Pengantar Perubahan." Makalah Pembukaan Kuliah Program Magister IImu Hukum UII. Yogyakarta. September 2001. HIm. 2.

5Moh. Mahfud MD. 1998. "Menegakkan Supremasi Hukum melalui Demokratisasi." Dalam Dahlan Thaib dan Mila Karmila Adi (editor). Hukum dan Kekuasaan." Yogyakarta. Fakultas Hukum Ull: HIm. 60. 
pemimpin-pemimpin bangsa adalah menjunjung tinggi HAM sebagai mahluk Tuhan yang sama kedudukannya di hadapan Al- Khaliq.

Cita hukum nasional pada waktu itu berwatak kontradiktif, antitesis dan antagonistik terhadap cita hukum kolonial. Bagi hukum kolonial berlaku dalil atau adagium macht is recht, kekuasaan adalah hukum, artinya kekuasaan ada di tangan yang menentukan hukum sewenang-wenang itu. Adapun bagi cita hukum nasional berdalil Recht is recht, Macht is macht. Hukum adalah hukum dan kekuasaan adalah kekuasaan. Kekuasaan harus timbul karena hukum. Bukan sebaliknya, yaitu hukum dirumuskan untuk kepentingan kekuasaan seperti dilakukan oleh kolonialisme. ${ }^{6}$

Hukum dan tata hukum (rechtsorde) dicipta oleh manusia untuk mengorganisasi dan menata kebersamaan hidup antar manusia. Hukum dan tata hukum niscaya menyesuaikan diri dengan realitas manusia. Tiap realitas seperti apa adanya itulah yang merupakan kebenaran, bukan pendapat subjektif manusia mengenai realitas. Manusia yang satu selalu dalam relasi saling tergantung pada manusia yang lain dan pada lingkungan tempat dia hidup. Dalam hal ini Soepomo mengatakan sebagai berikut: ${ }^{7}$

"segala manusia sebagai seseorang, -.golongan manusia dalam satu masyarakat dan golongan-golongan lain dan tiap-tiap masyarakat dalam pergaulan hidup (darma) sendiri-sendiri menurut kodrat alam dañ segala-galanya ditujukan kepada kebahagiaan lahir batin."

"Manusia sebagai seseorang tidak pernah terpisah dari manusia lain atau dari dunia luar, dari golongan-golongan manusia, malah segala golongan makhluk segala sesuatu bercampur baur dan bersangkut paut. Segala sesuatu berpengaruh pengaruhi dan kehidupan mereka bersangkut paut. Inilah ide totaliter, ide integralistik dari bangsa Indonesia, yang berwujud juga dalam susunan ketatanegaraan yang asli".

Hukum terus berkembang sesuai dengan perkembangan masyarakat yang tidak lepas dari cita hukum Indonesia yang telah diidentifikasi oleh para pendiri negara, yaitu: yang terumus sebagai empat pokok pikiran yang terkandung dalam Pembukaan Undang-Undang Dasar 1945, yang telah mendapat pengakuan rakyat Indonesia. Sebenarnya hukum dibentuk atau dibuat dengan memperhatikan cita hukum bangsa dan negara Indonesia yang menjadi penentu arah kehidupan sebagai rakyat yang teratur, bukan memperhatikan dan mengutamakan kepentingan penguasa.

Disinilah letak arti pentingnya fungsi cita hukum yang memberikan nilai-nilai keadilan dalam proses pembentukan hukum. Dalam

${ }^{6}$ Ruslan Abdul Gani. "Proses Perumusan Cita Hukum dan Asas-asas Hukum dalam Periode 1908-1945 (Pendekatan Historis - Empiris dan Teoritis - Analitis)." Majalah Hukum Nasional: Edisi Khusus 50 Tahun Pembangunan Nasional. HIm. 3.

'Syafroedin Bahar. 1992. Risalah Sidang BPUPKI. Jakarta: Sekretariat Negara.

${ }^{8}$ Abdul Kadir Besar. 1995. Implementasi Cita Hukum dan Penerapan Asas-asas Hukum Nasional Sejak Lahirnya Orde Baru . Majalah Hukum Nasional. Edisi Khusus 50 Tahun Pembangunan Nasional 1. Hlm. 30. 
hal 'ini Abdul Kadir Besar, ${ }_{2}^{8}$ dalam tulisannya yang berjudul "Implementasi Cita Hukum dan Penerapan:Asas-asas Hukum Nasional Sejak Lahirnya Orde Baru?: mengatakan fungsi cita hukum adalah: Pertama, Memberi makna pada hukum; Kedua, Membatasi lingkup hukum positif yang dapat dibentuk; Ketiga, Menetapkan ukuran untuk menilai adil tak adilnya süatu hukum positif. Substansi dari cita hukum adalah keadilan sebagai idea. Idea Keadilañ inilăh yang berhakekat sebagai cita hukum.

Secarà umum nilai-nilaj dasär cita-cita hukum bangsa Indonesia dapat dirumuskan sebagai berikut: ${ }^{9}$

1. Hukum nasional dibangun dengan mempertimbangkan kriteria rasional, dan menjungjung tinggi nilai-nilai spiritual, etik dan moral untuk memelihara budi pekerti kemanusiaan yang luhur dan memegang teguh cita-cita moral rakyat yàng luhur.

2. Hukum nasional dibangun atas prinsip penghormatan' harkat dan martabat manusia dengan memberikan jaminan hak asasi warga negara dan hak-hak sosial secara, selaras, serási dan seimbang. Hukum nasional harus mampu mencegah timbulnya ketidakadilan dalam masyarakat. Disimpulkan dari sila kemanusiaan yang adil dan beradab dan pokok pikiran kedua dan keempat UUD 1945.

3. Hukum nasional melindungi segenap bangsa Indonesia. Seluruh tumpah darah
Indonessia yang merdeka, bersatu, berdaulat, adil dan'makmur, memperkukuh perșatuan dan kesatuan bangsa dimana hanya ada satu hukum nasional yang mengabdi kepada kepentingan nasional. Disimpulkan dari sila Perșatuan Indonesia dan pokok pikiran kesatu Pembukaan UUD 1945.

4. Hukum. nasional dibentuk sesuai dengan prinsip negara yang berkedaulatan rakyat, artinya dengan.persetujuan rakyat melalui permusyawaratan perwakilan, agar hukum nasional sesuai dengan aspirasi rakyat sehingga mampu menjadi sarana untuk mengembangkan kesadaran, tanggung jawab dan menggairahkan peran serta dalam pembangunan dan menumbuhkan dinamika kehidupan bangsa dalam suasana tertib dan teratur. Disimpulkan dari sila kerakyatan yang dipimpin oleh hikmat kebijaksanaan dalam permusyawaratan/perwakilan, dan pokok pikiran ketiga Pembukaan UUD 1945.

5. Hukum nasional mengetengahkan nilai keadilan sosial dalam arti hukum nasional membuka jalan bagi terwujudnya pemerataan, keadilan sosial bagi seluruh rakyat Indonesia. Disimpulkan dari sila keadilan sosial bagi seluruh rakyat indonesia dan pokok pikiran kedua Pembukaan UUD 1945.

A. Hamid S. Attamimi, mengutip pendapat H.J. Van Eikema Hommes ${ }^{10}$ menyatakan bahwa meski merupakan titik akhir yang tidak

${ }^{9}$ Oka Mahendra, ... op. cit., Hilm.111-112.

${ }^{10}$ A. Hamid S. Attamimi. 1990. "Peranan Keputusan Presiden Republik Indonesia dalam Penyelenggaraan Pemerintahan Negara". Disertasi. Jakarta: Pascasarjana UI. HIm.309. 
mungkin dicapai, namun cita-cita hukum memberi manfaat karena mengandung dua sisi; Pertama, dengan cita hukum hukum positif yang berlaku dapat diuji, dan Kedua, kepada cita.hukum, hukum positif sebagai usaha menuju sesuatu yang adil dengan sanksi pemaksa dapat diarahkan. Lebih lanjut, dengan mengetengahkan pendapat Gustav Radbruch, ditegaskan bahwa cita hukum tidak hanya berfungsi sebagai tolok ukur yang bersifat regulatif, yaitu yang menguji apakah suatu hukum positif adil atau tidak, melainkan juga sekaligus berfungsi sebagai dasar yang bersifat konstitutif, yaitu yang menentukan bahwa tanpa cita hukum, hukum akan kehilangan makna sebagäi hukum."

Cita hukum Pancasila sebagaimana ditetapkan oleh para pendiri negara RI pada saat diproklamasikannya dan diundangkannya UUD 1945 ditetapkan sebagai norma yang tertinggi dalam tata kehidupan kenegaraan. Pancasila berfungsi sebagai norma dasar negara dan sebagai norma dasar fundamental negara. Serangkaian nilai itulah yang berlaku sebagai cita hukum, dan kemudian nilai-nilai itu ditetapkan sendiri pula sebagai norma tertinggi dalam negara. Dengan. demikian, bangsa Indonesia dan negara telah memiliki pegangan dalam, menempuh kehidupan bermasyarakat, berbangsa dan bernegara.

Pancasila sebagai. cita-cita hukum bangsa Indonesia adalah dasar negara, ideologi nasional, kepribadian bangsa Indoneșia yang telah diterima sebagai satu-satunya asas dalam kehidupan bermasyarakat, berbangsa dan bernegara. Pembangunan nasional dinyatakan sebagai pangamalan Pancasila sehingga keseluruhan semangat, arah dan gerak pembangunan dilaksanakan sebagai pengamalan semua sila Pancasila secara serasi dan sebagai kesatuan yang utuh. Sudah tentu termasuk pula pembangunan di bidang hukum yang merupakan bagian integral dari pembangunan nasional. Hukum nasional haruslah merupakan perwujudan nilai-nilai Pancasila, harus mengandung isi yang sesuai dengan nilai-nilai luhur Pancasila yang diterapkan secara konsisten yang merupakan pandangan hidup, kepribadian dan cita-cita bangsa.

Dalam membentuk hukum nasional nilainilai dan cita-cita hukum bangsa harus diindahkan. Hukum sebagai unsur peradaban suatu bangsa haruslah menjadi cermin dan parnyataan nilai-nilai yang hidup dalam jiwa bangsa. Hukum nasional yang demikian itu akan lebih didukung dan ditaati oleh masyarakat serta mampu menggerakkan masyarakat berperilaku sesuai dengan yang diharapkan, karena selaras dengan cita-cita hukum yang hidup dan berkembang di tengahtengah masyarakat.

Eugen Ehrlich pelöor ilmu hukum sosiologis (sociological jurisprudence) menyatakan antara laịn bahwa "pusat perkembangan hukum bukanlah terletak pada badan-badan legislatif, keputusan-keputusan yudikatif ataupun ilmu. hukum, akan tetapi

\section{$11 / b i d$}

${ }^{12}$ Soleman B. Toneko. 1993. Pokok-pokok Studi Hukum dalam Masyarakat. Jakarta: PT. Raja Grafindo Persada. Hlm. 7. 
justru terletak dalam masyarakat itu sendiri". ${ }^{12}$

Cita-cita hukum yang hidup di tengahtengah masyarakat yang bersangkutan secara deduktif dijabarkan ke dalam sistem hukumnya dan sebaliknya realitas sosial, tuntutantuntutan perkembangan dalam masyarakat secara induktif diangkat nilai-nilainya untuk menjadi masukan dalam melakukan pembatasan hukum yang tetap bersumber pada cita-cita hukum.

\section{Pembentukan Hukum Nasional}

Hukum adalah hasil dari suatu proses pertumbuhan yang dinamis, yang didasarkan pada keyakinan bahwa hukum itu terjadi sebagai suatu perencanaa dari satu situasi tertentu menuju kepada suatu tujuan yang akan dicapai. Artinya hukum bukan merupakan suatu tujuan, melainkan hanya sebagai alat untuk mencapai suatu tujuan.

Abdurrahman (1995: 141-148) berpendapat sekurang-kurangnya terdapat lima konsep mengenai hukum nasional: ${ }^{13}$

1. Mertokusumo, yáng berpendapat bahwa hukum nasional sebagai hukum positif yang berlaku di Indonesia;

2. Hartono, yang berpendapat bahwa hukum nasional sebagai ius constituendum, sebagai suatu sistem hukum yang dicitacitakan oleh bangsa Indonesia sejak memproklamasikan kemerdekaannya pada tanggal 17 Agustus 1945;

3. Rahardjo, yang berpendapat bahwa hukum nasional Indonesia sebagai hukum
Indonesia baru, yang lahir sebagai akibat dari kemerdekaan bangsa Indonesia dengan UUD 1945 sebagai intinya. Pendapat ini-menurut Abdurrahman dapat dipandang menjembatani pendapat yang pertama dan pendapat yang kedua di atas, sehingga dengan demikian dapat dikatakan bahwa hukum nasional sudah ada di Indonesia, akan tetapi belum lengkap;

4. Lev, yang menyatakan bahwa hukum nasional sebagai hukum yang berlaku secara nasional dengan sifat kenasionalaninya. Menurut Lev, bahwa hukum nasional dibedakan dengan hukum lokal (Local Law). Hukum nasional sebagai hukum kemerdekaan yang dilawankan dengan hukum nasional.

5. Koesno, yang berpendapat bahwa hukum nasional sebagai hukum yang mengandung berbagai arti, dan lebih lanjut memberikan penjelasan sebagai berikut:

a. Hukum nasional sebagai hukum yang dinyatakan berlaku secara nasional oleh pembentuk undang-undang nasional.

b. Hưkum nasional sebagai hukum yang bersumber dan menjadi pernyataan langsung dari tata budaya nasional.

c. Hukum nasional sebagai hukum yang bahan-bahannya (baik idiil maupun riii) primer adalah dari kebudayaan nasional sendiri dengan tidak menutup kemungkinan memasukkan bahan-bahan dari luar sebagai hasil

${ }^{13}$ Soejadi. 1999. Pancasila Sebagai Sumber Tertib hukum Indonesia. Yogyakarta: Cet. Pertama. Lukman Offset. Him. 57-58. 
pengolahan di bawah oleh perhubungan dengan luar nasional.

d. Hukum nasional sebagai pengertian politis yakni perlawanan antara kolonial dan nasional.

Dalam tiap-tiap pembentukan hukum, permulaannya adalah suatu perencanaan yang didasarkan pada suatu kenyataan kehidupan yang diarahkan ke suatu tujuan yang tidak yuridis, yaitu suatu kepentingan, atau. suatu nilai yang akan dicapai di waktu yang akan datang atau kepentingan dan suatu nilai yang akan diamankan, dengan mengadakan suatu perikatan atau suatu struktur organisasi yang disingkat dengan hukum.

Proses pembentukan hukum memerlukan suatu instrumen yaitu kekuasaan. Hukum dan kekuasaan mempunyai hubungan yang sangat erat. Hubungan itu dapat digambarkan seperti satu mata uang dengan dua sisi. Di satu sisi hukum itu adalah kekuasaan atau wewenang legal, dan di sisi yang lain hukum itu adalah aturan-aturan untuk mengatur tingkah laku manusia dalam masyarakat termasuk tingkah laku para penyelenggara negara. ${ }^{\text {is }}$

Dalam membentuk hukum nasional, nilainilai dan cita hukum harus dindahkan. Hukum sebagai ukuran peradaban suatu bangsa haruslah menjadi cermin dan pernyataan nilai-nilai yang hidup dalam jiwa bangsa. Seperti yang dikatakan oleh Von Savigny hukum adalah pernyataan jiwa bangsa (volkgeist).

Undang-Undang Dasar 1945 yang dipandang masih banyak mengandung kelemahan, memerlukan adanya perubahan agar sesuai dengan perkembangan situasi kenyataan dan keyakinan idiil dimana keduanya merupakan faktor dalam pembentukan hukum.

'Hukum dibentuk berdasarkan situasi untuk mencapai suatu tujuan. Penilaian mengenai situasi dan tujuan adalah bersifat idili; artinya sesuatu yang akan dicapai. Jadi, suatu gambaran mengenai masa depan. Penegasan mengenai masa depan inilah yang mendorong kita untuk mencapai tujuan yang ditetapkan hukum dengan cara-cara yang dirancangkan.

Keyakinan-keyakinan idiil adalah pandangan dalam masyarakat mengenai manusia dan martabatnya dalam hubungan interindividual, dan dalam hubungannya dengan penguasa, bentuk-bentuk kenegaraan dan kekuasaan, cita-cita bagi suatu kehidupan yang idili.

Mengenai isi hukum yang berlaku, sebagaimana diketahui bahwa semua' norma hukum lahir karena diberi bentuk hukum oleh aparat hukum yang kompeten. Yang diberi bentuk itu adalah asass-asas hukum. Penegasan ini menyimpulkan di satu pihak bahwa hukum positiflah yang merupakan hukum yang berlaku, dan di lain pihak bahwa hukum positif hanya mempunyai arti hukum jika dikaitkan dengan asas-äsas hukum. Asas-

${ }^{14}$ Salman Luthan." "Dialektika Hukum dan Kekuasaan". Jurnal Hukum No. 14. Vol. 7. Agustus 2000. HIm.83. 
asas hukum yang menentukan isi hukum yang berlaku mempunyai suatu konstansi relatif. Dalam tiap-tiap tertib hukum selalu ada asas hukum konstitutif yang dipositifkan.

Dalam membưat hukum yang formal, artinya hukum yanğ secara resmi dikeluarkan oleh negara dalam tingkatan produk hukumnya, sebaiknya harus diperhatikan materi muatan dari suatu peraturan perundang-undangan.

Para ahli umumnya berpendapat, materi muatan undang-undang dalam arti formele wet atau formele gesetz tidak dapat ditentukan lingkup materinya, mengingat undang-undang merupakan kedaulatan raja atau kedaulatan rakyat, sedangkan kedaulatan bersifat mutlak, ke luar tidak tergantung siapa pun, dan ke dalam tertinggi di atas segalanya. Dengan demikian, menurut para ahli itu semua materi dapat menjadi materi undang-undang kecuali undang-undang tidak berkehendak mengaturnya atau menetapkannya. ${ }^{15}$

Berbeda dengan pendapat tersebut, A. Hamid S. Attamimi, berpendapat bahwa materi muatan undang-undang Indọesia merupakan hal yang penting untuk diteliti dan dicari, oleh karena. pembentukan undangundang suatu negara bergantung pada cita negara dan teori bernegara yang dianutnya, pada kedaulatan dan pembagian kekuasaan dalam negara, pada sistem pemerintahan negara yang diselenggarakanya. ${ }^{16}$

Apabila dilihat pada tata susunan (hierarki) peraturan perundang-undangan negara Indonesia, hal ini bukan hanya ditetapkan semata-mata, melainkan lebih dikarenakan peraturan perundang-undangan Indonesia, selain dibentuk oleh lembaga-lenbaga yang berbeda, juga masing-masing mempunyai fungsi dan sekaligus materi muatan yang berbeda sesuai dengan jenjangnya sehingga tata susunan, fungsi, dan materi muatan peraturan perundang-undangan- selalu membentuk hubungan fungsional peraturan yang satu dengan yang lainnya.

Ada tiga unsur yang terdapat dalam peraturan perundang-undangan yaitu: Pertama, dari segi bentuknya peraturan perundangundangan adalah terbatas pada keputusan tertulis; Kedua, dari segi pembentukannya yaitu bahwa peraturan perundang-undangan harus dikeluarkan oleh yang berwenang; dan Ketiga, dari segi isi dan sifatnya, yaitu bahwa peraturan perundang-undangan mengatur tingkah laku mariusia dan mengikat secara umum (abstrak). Seperti yang dikemukakan oleh Baqir Manan, ${ }^{17}$ mengenai definisi peraturan perundang-undangan sebagai berikut:

"Peraturan perundang-undangan adalah setiap keputusan tertulis yang dikeluarkan pejabat atau lingkungan jabatan yang berwenang yang berisi aturan tingkah laku yang bersifat atau mengikat secara umum".

${ }^{15}$ A. Hamid S. Attamimi.1979."Materi Muatan Peraturan Pemerintah dan Perundang-undangan." Majalah Hukum dan Pembangunạn. Jakarta. HIm. 1.

${ }^{16} /$ bid.

${ }^{17}$ Baqir Manan. "Fungsi dan Materi Peraturan Perundang-undangan." Makalah Penataran Dosen Pendidikan dan Latihan Kemahiran Hukum BKS-PTN Bidang Hukum Sewilayah Barat Fakultas Hukum Universitas Lampung. di Bandar Lampung. 11 November 1994. HIm. 1. 
Adanya ketiga unsur yang terdapat dalam peraturan perundang-undangan tersebut, maka tampaknya tidak mudah untuk membuat suatü peraturan perundang-undangan yang baik dan dapat menciptakan keadilaik dan dapat menciptakan keadilum dalam masyarakat. Sebab, persoalan keadilan, ketertiban dan kepastian hukum merupakan bagian yang esensial dalam mengkaji persoalan hukum, artinya, ukuran keadilan, ketertiban dan kepastian hukum akan sangat tergantung dari filsafat hukum yang dianutnya dan pada gilirannya akan mélahirkan teori-teori pembentukan hukum yang berbeda.

Kendati demikian, secara teoritis terdapat tiga dasar pembentukan hukum agar produk hukum termasuk di dalamnya adalah undangundang mempunyai kekuatan berlaku sécara baik dalam masyarakat. Tiga dasar tersebut menurut Baqir Manan adalah yuridis, sosiologis, filosofis. ${ }^{18}$ Disamping ketiga unsur tersebut dalam proses pembentukan peraturan perundang-undangan diperlukan adanya keterampilan yang khusus yakni teknik perancangan. Untuk menghasilkan peraturan perundang-undangan harus dipenuhi empat dasar sekaligus yaitu yuridis, sosiologis, filosofis dan teknik perancangan.

Pertama, pemaknaan terhadap dasar yuridis adalah bahwa peraturan perundangundangan harus mempunyai keabsahan akan proses pembentukannya. Keabsahan ini meliputi kewenangan, materi muatan, sinkronisasi, dan ketaat-asasan peraturan yang labih rendah terhadap yang lebih tinggi. Kedua, yang dimaksud dengan dasar sosiologis adalah bahwa peraturan perundangundangan dimaksudkan untuk mewujudkan tertib kehidupan dalam masyarakat, artinya, dalam pembentukan peraturan perundangundangan harus dipertimbangkan betul suatu peraturan akan diberlakukan. dalam suatu masyarakat itu terus mengalami perubahan sosial. ${ }^{19}$

Ketiga, pemahaman dasar filosofis adalah bahwa pembentukan peraturan perundangundangan harus tetap melihat dan mengacu kepada nilai-nilai ideal yang ditempatkan sebagai filosofi bangsa, sebab, nilai-nilai filosofis yang berada dalam tataran ideal akan tetap mampu mengikuti dinamika perkembangan masyarakat, betapa pun masyarakat akan terus mengalami perubahan sesuai dengan tingkat perkembangan masyarakatnya.

Keempat, yang dimaksud dasar teknik perancangan adalah keterampilan khusus dalam pembentukan peraturan perundangundangan. Teknik perancangan ini tidak boleh diabaikan dalam membuat peraturan perundang-undangan yang baik. $^{20}$

Berdasarkan uraian tersebut di atas, dapat diketengahkan bahwa manakala terdapat suatu peraturan perundang-undangạn yang

${ }^{18}$ Baqir Manan. Op. Cit. HIm. 13.

${ }^{19}$ Lawrence M. Friedman.1975. The Legal Sistem, A Social Science Perspective. Russel Sage Foundation. New York. Hlm. 269. Dalam Syaifudin. Makalah " Pembentukan Sistem Hukum Nasional Kajian terhadap Penerapan Landasan Filosifis, Sosiologis dan yuridis Dalam Pembentukan Undang-undang. Periode 1999-2000," FH UII. Yogyakarta. 2000. HIm. 27.

${ }^{20}$ lbid. HIm. 18. 
tidak mempertimbangkan landasan yuridis, sosiologis, filosofis, dan tehnik perancangan dalam proses pembentukannya, maka secara teoritis peraturan perundang-undangan tersebut tidak dapat berjalan secara efisien dan efektif. ${ }^{21}$

Akan tetapi untuk dapat mewujudkan suatu peraturan perundang-undangan yang memenuhi empat landasan tersebut, nampaknya tidak mudah. Hal ini disebabkan oleh berbagai kendala yang muncul dalam pembentukan sistem hukum nasional. Namun kendala tersebut harus diatasi, mengingat dengan reformasi bangsa indonesia akan meletakkan supremasi hukum sebagai acuan - dalam masyarakat, berbangsa dan bernegara. Pada akhirnya, dapat dikemukakan bahwa esensi dari hidup bermasyarakat mencerminkan suatu ketertiban, dan suatu ketertiban mencerminkan adanya hukum. ${ }^{22}$ Akan tetapi, hukum di sini secara ideal adalah hukum yang dapat mewujudkan kepastian hukum, ketertiban hukum dan keadilan hukum, sebagaimana yang tertuang dalam cita hukum nasional dengan realita merupakan pekerjaan yang tidak ringan yang harus ditangani secara konseptual, terarah dan terencana.

Oleh karena itu, materi hukum nasional harus disusun dan dirumuskan secara jelas, tegas dan mengatur secara tuntas dan dalam bahasa yang mudah dimengerti, sebab pengaturan yang tidak jelas dan tuntas memberikan peluang untuk pelaksanaan hukum atau law inforcement yang tidak seragam, tergantung pada penafsiran dan kebijaksanaan aparatur penyelenggara negara atau pejabat yang bersabgkutan, sehingga memberikan peluang untuk membuat kebijakan yang tidak bijaksana, bahkan mungkin terjadi penyalahgunaan kekuasaan dan kesewenang-wenangan dalam pelaksanaan tugas.

Bangsa Indonesia harus mengakui, betapapun baiknya suatu peraturan perundang-undangan, namun ia masih mengandung banyak kelemahan. Jadi, peraturan perundang-undangan hanyalah merupakan inti dari hal yang sepenuhnya harus diutarakan. Betapa pun rasionalnya kita mengemukakan segala sesuatu itu dalam aturan perundang-undangan, namun sifatnya itu selalu dapat berubah-ubah. la hanya merupakan pernyataan yang tidak sempurna dari kehidupan masyarakat yang langgeng sifatnya. Setiap waktu masih harus bergantung pada keadaan dan tingkat pertumbuhan serta kebudayaan Indonesia, sehingga dalam tiaptiap kejadian yang konkrit ia harus mendapat penerapan yang disempurnakan pula.

Dalam hubungan ini, berkaitan dengan era reformasi yang membutuhkan perubahan dan pembaruan di bidang hukum, reformasi hukum harus dilakukan dengan mencakup dimensi teoritik dengan cara merubah paradigma hukum dan reformasi mengenai

${ }^{21}$ Maria Farida Indrati Soeprätō. 1998. Ilmu Perundang-undangan Dasar-dasar Pembentukannya Yogyakarta: Cet. Kesatu. Kanisius. HIm. 19.

22Padmo Wahyono. 1992. Sistem Hukum Nasional dalam Negara Hukum Indonesia. Pidato Ilmiah pada Peringatan Dies Natalis UI Jakarta ke 33. Jakarta: Cet. Kedua. Rajawali. 
praktek hukum baik menyangkut sistem kelembagaan dan reposisi aparat penegak hukum. Sebab;, selama ini hukum hanya dijadikan alat justifikasi terhadap șemua tindakan untuk melanggengkan kekuasaannya. Nampaknya penguasa Indonesia terpengaruh oleh teori hukum (jurisprudence) yang dikenal dengan ajaran "legisme" atau "positivisme" seperti yang diajarkan John Austin dan Kelsen, bahwa hukum itu semata-mata kehendak dari penguasa (command of the sovereign) dalam bentuk peraturan perundang-undangan. ${ }^{23}$

Disamping itu, ditinjau dari aliran hukum yang ada tampak model hukum Indonesia terlalu menekankan pada aspek legal-formal dan positivistik, sementara aspek sosiologisnya tidak diperhatikan. Akibatnya hukum tidak sesuai dengan nilai yang berkembang dalam masyarakat. Hukum tidak responsif dengan tata nilai dalam masyarakat. Hal ini disebabkan oleh konfigurasi politik otoriter sehingga malahirkan produk hukum konservatif, yang isinya lebih mencerminkan visi sosial elit politik atau mencerminkan keinginan pemerintah, bersifat positivistisinstrumentalis, yakni menjadi alat pelaksanaan ideologi dan program negara. Proses pembuatan hukum pun sentralistik (didominasi) oleh eksekutif. ${ }^{24}$ Produk hokum seringkali hanya dijadikan landasan dan upaya perlindungan atas kekuasaan, meskipun menyadari pentingnya penegakan hukum (law enforcement)... Hukum seringkali disalahgunakan demi melindungi kepentingan pejabat tertentu.

Kebekuan hukum selama Orde Baru dengan sikap sakralisasi terhadap UndangUndang Dasar 1945, hukum yang diciptakan pun lebih berpihak kepada kepentingan orangorang tertentu. Setelah memasuki era reformasi dengan tekad merombak hukum yang tidak bermakna secara keseluruhan, maka upaya pembaruan hukum dalam bidang perundang-undangan harus mengindahkan ketentuan yang memenuhi nilai-nilai. filosofis, sosiologis dan yuridis sehingga lebih menyentuh rasa keadilan masyarakat.

Jika dikaji secara lebih mendalam, sebenarnya bangsa Indonesia tidak mempunyai program yang jelas terhadap upaya pembaruan perundang-undangan dan aturan dasar, lebih-lebih kalau dicermati hasil perubahan UUD 1945 baik pada perubahan pertama, kedua dan ketiga, masih ada beberapa pasal yang menonjolkan kompromi politik yang sebetulnya berimplikasi jangka pendek dan masih banyak mengundang perdebatan. Adnan Buyung Nasution ${ }^{25}$ menilai, proses dan hasil perubahan pertama dan kedua UUD 1945 oleh MPR masih berantakan. "saya melihat hasil perubahan UUD 1945 justru mengacaukan

${ }^{23}$ E. Utrecht (et. Al). 1983. Pengantar Dalam Hukum Indonesia. Jakarta: Cet. 10. SH, HIm. 115. yang dikutip kembali oleh Bagir Manan. 1992. Dasar-dasar Perundang-undangan Indonesia. Jakarta: INDHILL. Co. Him. 2.

${ }^{24}$ Moh. Mahfud MD: 1998. Politik Hukum Indoriesia. Yogyakarta: UII Press. HIm. 196. Bahan kuliah Politik Hukum Program Magister Ilmu Hukum Ull Yogyakarta. Tanggal 14 September 2001.

${ }^{25}$ Kompas. 16 April 2001 
ketatanegaraan Indonesia". 'Hal ini berarti," perubahan UUD 1945 masih akan terus berlangsung dalam rangka membangun check and balance pada sistem pemerintahan Indonesia. Sebab, dilihat dari kondisinya, perubahan UUD 1945 dilakukan seketika setelah tumbangnya Orde Baru yang membuka peluang reformasi UUD 1945.

Suasana ini mirip saat penyusunan pertama kali UUD 1945 yang dibuat dalam kondisi darurat, bersamaan dengan Proklamasi Kemerdekaan Indonesia. Suasananya masih dalam nuansa penjajahan Jepang. Padahal menurut K.C. Wheare ${ }^{26}$ perubahan konstitusi harus dilakukan dengan pertimbangan yang masak, tidak secara serampangan dan dengan sadar (dikehendaki), agar rakyat diberi kesempatan untuk menyampaikan pandangannya sebelum dilakukan perubahan. Pendapat senada dilontarkan oleh Bambang Widjajanto ${ }^{27}$, yang mengatakan bahwa mengingat konstitusi adalah suatu kontrak sosial antara rakyat dan negara, prinsip konsultasi publik harus lebih ditekankan dan diperluas. UUD jangan hanya menjadi milik sekelompok kecil elit politik pusat saja:

Wajar jika hasil amandemen UUD 1945 masih banyak mengandung perdebatan; kekurangan; bahkan telah menimbulkan pergeseran kekuasaan dari presiden (executive heavy) kepada parlemen (legislative heavy). Hal ini dapat dilihat dari hasil perubahan pertama UUD 1945 yang secara substantif lebih banyak 'melakukan' pengurangan dan pembatasan kekuasaan eksekutif (Pasal 5, 7, 13, 14, 15, 20). Demikian pula pada hasil perubahan kedua, hak-hak Anggota DPR yang selama ini hanya diatur di dalam Peraturan Tata Tertib DPR RI dan UU No. 4 Tahun 1999 tentang Susunan dan Kedudukan: MPR, DPR dan DPRD, ditingkatkan ke dalam materi UUD 1945 (Pasal 20A). Jaminan Hak Asasi Manusia semakin diakui keberadaannya di dalam UUD 1945 (Pasal 28A-28J). Pengaturan tentang kedudukan dan hubungan kelembagaan antara Pemerintah Pusat dan Daerah lebih diperjelas (Pasal 18, Pasal 18A dan Pasal 18B). Akan tetapi, hasil perubahan UUD 1945 tersebut secara umum banyak mendapat sorotan tajam dari berbagai kalangan, khususnya para ahli konstitusi. Menurut mereka, yang dilakukan oleh MPR tidak tepat disebut sebagai perubahan karena materi yang diubah dan ditambah sangat banyak. Perubahan itu lebih tepat disebut penggantian, karena:secara konseptual perubahan yang pertama, kedua dan ketiga, sangat parsial dan tidak ufuh sebagai satu kesatuan yang integral. Demikian juga: Tommi Legowo, ${ }^{28}$ wakil dari CSIC (Centre for Strategic and International Studies) menilai, proses maupun substansi amandemen yang telah dan masih akan dilakukan oleh MPR melalui tahap keempat 2002 tampak masih jauh dari harapan. Dari segi proses, ia menilai amandemen yang berlangsung selama ini bersifat elitis, karena

${ }^{26} \mathrm{~K}$. C. Wheare. 1975. Modern Constitution. Hlm. 83. sebagaimana dikutip oleh Sri Soemantri dalam Prosedur dan Sistem Perubahan Konstitusi. Cet. Keempat. Bandung: Alumni. Him. 78.

${ }^{27}$ Republika. 6 Maret 2002.

${ }^{26}$ Media Indonesia. 2 Maret 2002 
waktu yang digunakan untuk penyerapan aspirasi rakyat sangat sedikit. Inisiatif MPR untǘk mendàtangi anggota masyarakat dan. menanyai secara langsựng apa yang menjadi harapan dan kepedulian mereka terhadap perubahan UUD ' 1945 támpak sangat kurang, sehingga hasitnya belum banyak menyentuh persoalan rumit yang dihadapi masyarakat.Hal ini . bertentangan dengan semañgat amandemen, yakni melahirkan konstitusi baru, yakni konstitusi rakyat yang melayani dan mengayomi seluruh rakyat tanpa kecuali. Karena menurut Tommi, konstitusi baru harus menjadi landasan dan acuan dasar. Bụkan saja untuk menyelesaikan persoalanpersoalan rumit yang sedang dihadapi bangsa, melainkan juga untuk membangun diri kita menjadi a new community of civilizatioan (komunitas masyarakat baru) yang sejajar dengan bangsa lain.

Menanggapi kritikan tersebut, Theo Sambuaga menyatakan PAH I BP MPR sudah berusaha maksimal melakukan amandeman sesuai kehendak rakyat, yakni bukan membuat konstitusi baru, melainkan untuk melengkapi dan memperkuat, konstitusi yang ada. Sedangkan Koalisi Organisasi Non Pemerintah (Ornop) menilai bahwa MPR telah gagal melakukan amandeman UUD 1945, hal itu karena MPR merupakan bagian dari masalah yang sedang dihadapi dan bukan menyelesaikan masalah yang ada. Dalam perubahan UUD keempat akan melibatkan partisipasi publik secara langsung, akan tetapi menurut Bambang Widjojanto, ${ }^{29}$ partisipasi publik hanya diberlakukan secara simbolik dalam proses perubahan konstitusi itu. Keputusan akhir amandemen UUD1945 berada di tangan sebagian kecil anggota $B P$ MPR yang. duduk dalam tim perumus serta tim lobi. Apabila ada kunjungan wakil rakyat: ke daerah, hal 'itu' bukan untuk menjaring: aspirasi rakyat, melainkan- lebih: mempraktikkan komunikasi satu arah dengan. sebagian peserta berasal dari kalangan pemerintah daerah dan partai politik. $\quad \cdots, \ldots$,

UUD 1945 setelah diubah sustru: kehilangan "ruhnya" sebagai konstitusi ideal. Bukan berarti sebelum diubah UUD 1945. sudah ideal, tetapi hubungan antara bunyi. pasal yang satu-dengan yang lainnya jadi kurang sinkron, sistem apa yang. ingin dibangun melalui perubahan tersebut menjadikabur. Apakah kita akan mengarahkan pemerintahan negeri ini dengan model presidensiil ataukah parlementer. Apakah melalui UUD yang sudah diubah tersebut sudah cukup efektif untuk mengontrol kekuasaan, mengorganisasikan negara secara ideal?

Melalui perubahan ketiga, telah lahir lembaga baru yang bernama mahkamah. konstitusi yang berwenang antara lain menguji pendapat DPR tentang usulan pemberhentian Presiden dan/atau Wakil Presiden, dugaan pelanggaran oleh Presiden dan/atau Wakil Presiden menurut UUD, memutus sengketa kewenangan. lembaga negara. yang kewenangannya diberikan oleh.: $U U D_{\text {; }}$ pembubaran partai politik dan perselisihan hasil pemilihan umum. Lembaga mahkamah konstitusi ini sebelumnya tidak dikenal di

${ }^{29}$ Ibid. 
dalam UUD 1945. Terlepas dari segala macam kekurangan yang ada, perubahan UUD 1945 tentu diharapkan akan mampu menciptakan keseimbangan kekuasaan (checks and balances) diantara lembagalembaga tinggi negara. Walaupun hingga saat ini langkah konfrontatif atau pertarungan antara elit politik masih sering mewarnai terutama pada saat perhelatan sidang rakyat namun, hal ini harus dianggap wajar, sebagai proses pendewasaan berdemokrasi.

Kondisi demikian menurut Moh. Mahfud MD, adalah pengaruh dari konfigurasi politik anomi atau anomali, yaitu suatu situasi yang muncul yang disebabkan oleh tiadanya nilai aturan-aturan yang mantap yang harus ditaati atau tidak dapat dipedomani karena aturan baru belum terbentuk dan aturan lama sudah dibuang, sehingga melahirkan produk hukum yang labil, artinya sebelum naskah undangundang dasar yang utuh itu diselesaikan maka periode sekarang harus dianggap sebagai masa transisi: ${ }^{30}$

Sebenarnya bangsa Indoneșia tidak mempunyai grand desain ${ }^{31}$ atau program yang jelas untuk melakukan pembaruan perundang-undangan, sehingga menyebabkan adanya pengingkaran rasa keadilan yang dilakukan oleh penegak hukum dalam menyelesaikan atau menangani kasuskasus hukum. Finalisasi terhadap kasus-kasus yang muncul harus mendapat perhatian serius, dalam arti tidak sekedar wacana agar keadilan dan kepastian hukum betul-betul dirasakan oleh masyarakat.secara keseluruhan.

\section{Simpulan}

Untuk membentuk dan menghasilkan hukum yang ideal dan baik harus dipenuhi empat dasar sekaligus yaitu, yuridis, sosiologis, filosofis dan teknik perancangan, sehingga dapat menciptakan keadilan; ketertiban dan kepastian hukum dalam masyarakat.

Ditinjau dari berbagai aliran hukum yang ada tampak model hukum Indonesia terlalu menekankan pada aspek legal-formal dan positivistik. Akibatnya produk hukum yanig dihasilkan lebih bersifat praktis-pragmatis. Sampai saat ini pun hukum belum mampu menciptakan rasa keadilan, karena kita tidak mempunyai grand program atau program yang jelas dalam upaya pembaruan hukum.

Perubahan UUD 1945 yang telah dilakukan tidak menjiwai falsafah Pancasila, dan kurang memenuhi rasa keadilan karena proses dan substansinya tidak mencerminkan kehendak rakyat dalam arti yang sebenarnya.

Untuk itu peran cita hukum sangat penting sebagai penentu arah bagi terciptanya citacita masyarakat, lebih-lebih di era reformasi dimana pembaruan hukum merupakan kebutuhan yang mendesak terutama dalam upaya perubahan UUD 1945 yang memang. sudah saatnya diperbarui. Cita hukum yang merupakan nilai-nilai filosofis dalam suatu bangsa secara ideal harus terwujúd dalam tatanan sistem hukum nasionalnya dan berfungși sebagai pedoman yang memandu, mengarahkan agar hukum nasional benarbenar merupakan perwujudan nilai-nilai luhur

${ }^{30}$ Forum Keadilan. 11 November 2001.

${ }^{31}$ Adnan Buyung Nasution."Tody's Dialogue". Metro TV. 18 Desember 2001. 
Pancasila dan secara "dinamis : dapat $A^{i}$ Metro Ț: 18 Desember 2001 memenuhi tuntutan perkembangan. zaman yang terus bergerak maju.

\section{Daftar Pustaka}

Asshiddiqie, Jimly. UUD Negara Kesatuan RI, Pengantar Perubahan. Makalah Kuliah Perdana Program: Magister IImu Hukum Ull. Yogyakarta. 13 September. 2001.

Attamimi, A. Hamid S. 1990. Peranan Keputusan Presiden Rl Dalam Penyelenggaraan: Pemerintahan Negara. Disertasi: Pascasarjana Ul. Jakarta.

B. Soleman. 1993. Pokok-pokok Studi Hukum Dalam Masyarakat. Jakarta: Rajagrafindo Persada.

Forum Keadilan No. 32, 11 November 2001. . Jurnal Hukum No. 14. Vol. 7, Agustus 2000. Kompas. 16 April 2001.

Majalah Hukum Nasional, edisi Khusus' 50 Tahun Pembangunan Nasional No." 1 -Tahun 1995:

Mahfud, Moh. MD. 1998. Politik Hukum Indonesia. Yogyakarta: LP3ES dan Uill Press.

Malian, Sóbirin. 2001.Gagasán Perlunya' Kónstitusi Baru Pengganiti UUD 1945. Yogyakarta: Cet. Pertama. UII' Press. -

Manan, Bagir. 1992. Dàsar-dasar Perundangundangan Indonesia. Jakarta: IND- HILL.CO.

Media Indonesia. 2 Maret 2002

Ràhardjo, Satjipto. 1991. IImu Hukum. Bandung: Citra Aditya Bakti. Cet. Ketiga.

Rasjidi, Lili dan B. Arief Sidharta. 1989. Filsafat Hukum Madżhab dan Refleksinya. Bandung: Cetakan Pertama. Remaja Karya Offset.

Republika. 6 Maret 2002

Sidharta, Bernard Arief. 1999. Refleksi tentang Struktur IImu Hukum. Bandung: Cet. 1. Mandar Maju.

Soeprapto, Maria Farida Indrati.1998. IImu Perundang-undangan Dasar-dasar dan Pembentukannya Yogyakarta: Kanisius.

Soejadi. 1999. Pancasila Sebagai Sumber Tertib Hukum Indonesia. Yogyakarta: Lukman Offset

Soemantri, Sri M. 1997: Prosedur dan. Perubahan Konstitusi. Bandung: Cet. IV. Alumni

Syaifudin, "Pembentukan Sistem Hukum Nasionai, kajian terhadap Penerapan Landasan Filosofis, sosiologis dan Yuridis Dalam Pembentukan undangundang periode 1999-2000", Makaläh diskusi di FH Ull. Yogyakarta. 2001.

Thaib, Dahlan dan Mila Karmila Adi (Editor). 1998. Hukum dan .Kekuasaan. Yogyakarta: Fakultas. Hukum Ull. 